an examination I was delighted at not finding any placenta near the os uteri. The head was presenting; the labour was quick and natural ; and, on the expulsion of a thin but healthy child, the whole cause for our previous alarm was very satisfactorily but unusually explained. The child was expelled, together with the placenta, by the last pain, when I found the funis was so very short that the abdomen of the child appeared to be almost in contact with the placenta; in fact, the cord was not quite six inches long, and $I$ had some little difficulty in putting the two ligatures on it. Never having met with any case like this, during an extensive practice for thirtyfive years, I have stated it, in order to afford one gleam of comfort to my professional brethren, when uterine hæmorrhage occurs in the latter months of pregnancy, since what has occurred once may occur again.

Kenton, July, 1842.

\section{POISONING WITH OPIUM.}

\section{TO THE EDITORS OF THE PROVINCIAL MEDICAL JOURNAL.}

Gentremen,-If you think the following case worthy of insertion in your Journal, I shall be glad if you will give it a place. There are two or three points in it which deserve remark: the near approach to death of the little patient; its early age for mechanical treatment; and the recklessness of the mother in giving it so large a dose of opiate-a practice which is, I fear, but too common in the class to which she belongs; and the complication of the symptoms with teethinga condition requiring attention in the after treatment. Your obliged servant, ROBERT STORR\&.

Doncaster, July 22, 1842.

About six o'clock in the evening of July 4, Catherine Doyle, aged seven months, was brought to my surgery apparently in a dying state. She was cold and pulseless, with livid lips and dusky countenance; eye-lids half closed ; the globe of the eye upturned ; pupils contracted; there was great stupor. It was stated by the mother, who came with the child, that as it had been restless for some time, she had been advised to give it a little laudanum, and had consequently given it about half a teaspoonful in the forenoon. At noon, when her husband came home, he thought it looked very ill, but the mother dared not tell him what she had done, as she began herself to think that she had done wrong. In the afternoon she also became seriously alarmed, and was advised by one of her neighbours to take the child to the dispensary, whence it was brought to me. It was then in the state above described. I saw there was no time to be lost, as it seemed to be in a dying state. I determined, therefore, to try the stomach-pump, and in lieu of the ordinary stomach-tube, which was, of course, much too large for so young an infant, I adapted to the syringe the largest elastic gum-catheter $I$ had, and found it serve the purpose required very well. I injected into the stomach about a pint of warm water, having in solution two grains of sulphate of zinc, and brought the whole of it back again; for before $I$ had finished withdrawing the fluid, spontaneous vomiting came on, and the stomach was entirely emptied; the fluid returned, smelling strongly of laudanum.

As soon as this was done, and the tube withdrawn, the child's head fell, and I supposed it was dead. By artificial respiration, however, putting the child into a hot bath immediately, applying stimulants to the nostrils, \&c., sensation and respiration returned. After a short time the pulse began to be felt, and in about an hour the child seemed to be much better, except that it was in a state of great exhaustion. It was now put into warm flannel, and placed in a child's cot in my nursery, where I left it for a time under competent superintendence. I had not long left the house before the child was seized with a violent convulsion. I was soon sent for, when mustard plasters to the feet, hot bottles, \&c., were applied, and as I found it was cutting two teeth, I lanced its gums, and subsequently applied a leech to the forehead. From this time it gradually recovered, and was able to be removed home about eleven o'clock, p.m. The mother was requested for some hours not to let it sleep long at a time; and in the morning, when I called, I found the little patient quite restored.

\section{LUXATION OF THE TIBIA.}

TO THE EDITORS OF THE PROVINCIAL MEdical JOURNAL.

Gentlemen, - The attention of your readers having been recently drawn* to the subject of luxations of the knee-joint, the remarkable discrepancy of authors in describing the position of the leg in the dislocation backwards, has been brought under notice. In the following case, the leg was at right angles with the thigh, and the ligament of the patella was not tornin these points differing from each of the opposite conditions of the limb, mentioned by Sir A. Cooper and Boyer (vide Cooper's Surgical Dictionary, seventh edition). As it is probable that the circumstances which occasion these varieties, and the comparative frequency of each variety, will only be determined by the multiplication of individual instances, may $I$, on this ground, beg the insertion of the following notes? Your obedient servant,

Thomas T. Griffith.

Wrexham, July 27, 1842

January, 1821.-I was called to S. Evans, aged forty, of spare habits, but strong muscular frame. Whilst at work, above a very large wheel moving in connection with a steam-engine, he had fallen on its edge, and had been forced doubled through an incredibly small space between the wheel and a wall. The scalp was severely lacerated and contused; the interspinous ligament of the fifth and sixth dorsal vertebræ was torn through, and the head of the tibia was thrown behind the femoral condyles; the leg was at right angles with the thigh; the patella closely set on the trochlea, and its ligament on the full stretch, but not ruptured. After several ineffectual attempts at reduction, I proceeded in the following manner :-The man lay on his back, with the nates on the edge of

F* See the Nos, for May 14, June, 11 and 18. 
the bed. I stood in front of the knce, with a thick shawl passed around the head of the tibia and my neck; my hands rested on the condyles; the thigh was well fixcd; an assistant was directed to carry the heel backwards, in order to free the anterior edge of the head of the tibia from the condyles, and at a given point, to extend the leg with a rapid sweep, whilst I drew the head of the bone forwards and upwards. In this way the reduction was immediately effected; the limb was laid in the extended position on a splint, and kept cool by appropriate applications ; but little inflammation or swelling supervened, and within five weeks, the patient had so far recovered the use of the joint as to walk comfortably with the assistance of a stick.

\section{SOME ACCOUNT}

$$
\text { OF THE }
$$

\section{OFFICE OF CORONER, AND THE}

PROCEEDINGS OF THE CORONERS' COURT,

WITH SUGGESTIONS FOK THE IMPROVEMENT OF THESE PROCEEDINGS.

By Martin H. Lyncil, M.D.

In several of our counties and boroughs the office of coroner is now held by medical men; and, perhaps, the most important portion of the testimony taken at inquests is that given by the medical witnesses, who, owing to the usual promptness of procedure in the coroners' court, are enabled to give material evidence whilst the body is free from decomposition, or, at all events, in such a state as to be capable of furnishing a corroboration of correct views, or a refutation of incorrect opinions, as to the cause of death. Indeed, the facilities afforded for ascertaining whether the deceased has died in the course of nature or not, have co-operated with the agency of the jury and of a judge-now in all places, formerly in most places, elected by the people, and quitc independent of the crown-in attaching a high degree of importance in the minds of the public to the proceedings on coroners' inquests-a character which they have not altogether forfeited, although it is pretty generally known that the inquiry has often been conducted in a very inefficient manner, in consequence of the ignorance, carelessness, or stupidity of the coroner, the jury, or the witnesses-nay, sometimes of all these parties. In fact, mere blunders and negligence are overlooked, because, it is well understood, the proceedings are so framed by law that it is scarcely possible a corrupt verdict should be returned.

Without further introduction, then, than this allusion to the prominent position occupied by members of the medical profession at coroners' inquests, we shall proceed to consider these inquiries, with the view of suggesting a few amendments in the legislation regarding them-amendments which, in our opinion, are urgently called for; and the plan we deem best calculated to exhibit any imperfections in the laws at present in force, and to point out the means of improving them, is the following:- We shall, in the first place, give some account of the mode of conducting investigations as to the cause of death in England, France, and Scotland, especially with a view to the methods adopted in each country of employing the aid of medical science; and, secondly, prepared by the previous steps, we shall enter into a comparison of the course pursued in these countries, and endeavour, upon this comparison, to found some suggestions for the improvement of the laws of England, that have reference to proceedings of this kind.

In England, the office of coroner is of very ancient date. Some have said, it is coeval with that of sheriff; but, however this may be, it is certain there were coroners in the time of Alfred, for that king punished with death a judge who sentenced a party to die upon the coroner's record, without allowing the prisoner liberty to traverse. The office is also mentioned by Athelstan, in his charter to Beverly. The first Act of Parliament referring to it is that De Officio Coronatoris, 4th Edward I., A.D. 1275. And it is in virtue of this act that the existence of the coroners' court is rendered essential, and the jurisdiction of its judge exercised; for although some of the duties imposed by it on the coroner are, in the present day, never performed by him, it has never been repealed, and the bills relating to this subject, passed in subsequent reigns, merely defined the meaning and intentions of this statute, or added to the efficiency of the coroners' court, by providing that the proceedings instituted by it should be honestly and diligently conducted.

That the office of coroner did not exist amongst the ancient Britons, is sufficiently proved by the preamble to the statutes of Wales.* The preamble proceeds thus:-" Whereas the Divine Providence, which is unerring in its own government, among other gifts of its dispensation, wherewith it hath vouchsafed to distinguish us and our realm of England, hath now of its favor wholly and entirely transferred, under our proper dominion, the land of Wales, with its inhabitants; we, therefore, under the Divine will, being desirous, \&c.,

have caused to be rehearsed, before us and the nobles of our realm, the laws and customs of those parts hitherto in use, which, being diligently heard and fully understood, $* * * *^{*} * * * * * *$ some thereof we have allowed, and some corrected, and we have likewise commanded certain others to be ordained and added thereto."

Under the latter head (of additions to the existing laws of the principality), the statute enacts that there be sheriffs, coroners, and bailiffs in the Welsh counties, and that " the coroners shall be chosen by the king's writ, the tenor whereof is to be found among the original writs of the Chancery."

Hence, it can hardly be doubted, the office and laws of coroner must either have been introduced into England by our Saxon ancestors on their first arrival, or have had their origin at a subsequent period of the sway of the Saxon princes, and predominance of the Saxon race.

At a remote period the office was one of considerable dignity, and the coroner was required, during the early part of the Norman rule, to be a knight; but, by the statute (28th Edward III., c. 6, A.D. 1355), it was enacted simply that the coroners - 12th Edward I., A.D. 1284. 